\title{
GLOBAL GREEN: WHY A GLOBAL DIESEL REGULATION FOR MOBILE SOURCES MIGHT BE A GOOD IDEA
}

\author{
Joseph E. Sawin *** \\ I. INTRODUCTION
}

Air pollution knows no borders. ${ }^{1}$ Prevailing winds have been found to carry particulates from Asian sources across the Pacific Ocean to the western United States, and likewise, from eastern U.S. sources across the Atlantic to Europe. ${ }^{2}$ A primary source of this air pollution is diesel exhaust emissions. ${ }^{3}$ Diesel exhaust emitted from mobile sources creates health and environmental concerns because it contains both particulate matter and gases that contribute to ozone (a component of smog), acid rain, and global climate change. ${ }^{4}$ According to the United States Environmental Protection Agency (EPA), particulate matter alone causes 15,000 premature deaths each year in the United States. ${ }^{5}$ Generally, regulated diesel exhaust emission gases include nitrous oxides $\left(\mathrm{NO}_{\mathrm{x}}\right)$, hydrocarbons $(\mathrm{HC})$, carbon monoxide $(\mathrm{CO})$, and particulate matter (PM). ${ }^{6}$ Beginning in 2014 the EPA will regulate an additional gas, carbon dioxide $\left(\mathrm{CO}_{2}\right)$, a common greenhouse gas found in the exhaust of hydrocarbonburning combustion systems such as diesel engines. ${ }^{7}$

Although air pollution travels internationally, global diesel engine and

* J.D., 2012, Indiana University Robert H. McKinney School of Law, Indianapolis, Indiana; M.S., 2004, Automotive Engineering, University of Michigan, Ann Arbor, Michigan; B.S., 2000, Mechanical Engineering, Purdue University, West Lafayette, Indiana. I would like to thank my wife, Jenny, and my mother, Mary, for all of their support, feedback, and encouragement without which this Note would not have been possible.

** Recipient of the 2011 Henry B. Blackwell II Prize for best student note or article on an international law topic in the Indiana International \& Comparative Law Review.

1. U.S. Envtl. Prot. Agency, The Plain English Guide to the Clean Air ACt 10-11 (2007), available at http://www.epa.gov/airquality/peg_caa/pdfs/peg.pdf.

2. Robert Lee Hotz, Asian Air Pollution Affects Our Weather, L.A. TIMEs (Mar. 6, 2007), http://articles.latimes.com/2007/mar/06/science/sci-asiapollute6.

3. See U.S. Envtl. Prot. Agency, Diesel Exhaust in the United States (2003), available at http://epa.gov/cleandiesel/documents/420f03022.pdf.

4. Id.

5. Id.

6. How Emissions Are Regulated, DIESELNET, http://www.dieselnet.com/ standards/intro.html (last visited April 14, 2012).

7. Greenhouse Gas Emissions Standards and Fuel Efficiency Standards for Medium-and HeavyDuty Engines and Vehicles, 76 Fed. Reg. 57106 (Sept. 15, 2011); Press Release, U.S. Envtl. Prot. Agency, DOT, EPA Propose the Nation's First Greenhouse Gas and Fuel Efficiency Standards for Trucks and Buses (Oct. 25, 2010), available at http://yosemite.epa.gov/opa/admpress.nsf/ d0cf6618525a9efb85257359003fb69d/9b3706622f4ac560852577c7005ea140!OpenDocument. 
equipment manufacturers are regulated only by the local laws of the countries in which they conduct business. ${ }^{8}$ Regulating entities can be divided into three subsets: (1) entities that set their own diesel exhaust emission standards ("first adopters"), (2) entities that accept products into their respective countries from a first adopter ("second adopters"), and (3) entities that do not have regulations because their governments have not enacted any or because a governing body simply does not exist ("unregulated" countries).

For many years, a balance has existed in the world between environmental and economic interests. Developed countries have placed greater emphasis on reducing pollution, whereas developing countries have focused primarily on economic development. ${ }^{10}$ This Note proposes the adoption of an international diesel exhaust emission standard by weighing both the environmental and economic costs and benefits of a global mobile-source diesel regulation. The following discussion illustrates that, with the proper balance of regulations, it is possible to achieve economic growth through trade while also protecting the environment. Part II of this Note provides a brief technical background on diesel exhaust emissions and discusses existing regulations among first and second adopters. Part III outlines the environmental issues surrounding air pollution from diesel exhaust emissions and discusses the environmental impacts of unregulated or under-regulated countries. Part IV discusses the barriers that have prevented the adoption of a global diesel emission regulation, and Part $V$ analyzes the economic costs associated with the current structure of multiple diesel regulations. Finally, Parts VI and VII suggest that a global regulation may be the most economically efficient solution to the diesel exhaust emission problem, offering a roadmap for the adoption of an international standard.

\section{A BACKGROUND ON DIESEL EMISSIONS}

"The single most important reason that diesel engines are used in most applications is their superior energy efficiency." " Compared to spark-ignited engines of similar power outputs, diesel engines perform the same amount of work while consuming less fuel. ${ }^{12}$ This advantage is the result of several

8. U.N. Dep't of Econ. \& Soc. Affairs, Global Overview on Fuel Efficiency and Motor Vehicle Emission Standards: Policy Options and Perspectives for International Cooperation, secs. 13-15, CSD19/2011/BP3 (2012), available at http://www.un.org/esa/dsd/resources/ res_pdfs/csd-19/Background-paper3-transport.pdf.

9. Interview with Robert Jorgensen, Exec. Dir., Cummins Inc. Prod. Envtl. Mgmt., in Columbus, Ind. (Jan. 5, 2011).

10. Daniel C. Esty, Greening the GatT: Trade, Environment, and the Future 10 (1994); see generally GREENING INTERNATIONAL LAW (Philippe Sands ed., 1994).

11. Charles River Assocs., Diesel Technology and the American ECONOMy 2 (Oct. 2000), available at http://www.dieselforum.org/index.cfm?objectid=93C6F9F0-9381-11 E098E9000C296BA163.

12. Id. 
characteristics, "including reduced pumping losses due to lack of (or greatly reduced) throttling, and a combustion cycle that operates at a higher compression ratio and with a very lean air/fuel mixture relative to an equivalent-performance gasoline engine." 13 Typical efficiency improvements range between twenty-five and thirty-five percent depending on the application,${ }^{14}$ of which there is a wide variety. Diesel engines are used in lightduty passenger cars, ${ }^{15}$ heavy-duty trucks, ${ }^{16}$ buses, ${ }^{17}$ construction and farm equipment, ${ }^{18}$ electrical power generators, ${ }^{19}$ maritime vessels, ${ }^{20}$ and locomotives. ${ }^{21}$

\section{A. Diesel Exhaust Emissions}

Diesel emissions are created from the combustion process of an internal combustion engine..$^{22}$ Because of stringent standards imposed by the EPA in the 1990s, diesel engine manufacturers began employing technologies such as injection timing retard and intake air cooling in order to reduce $\mathrm{NO}_{\mathrm{x}}$ emissions. ${ }^{23}$ The EPA also placed a major emphasis during this period on reducing particulate matter from heavy-duty engines. ${ }^{24}$ As a result, diesel manufacturers achieved significant PM reductions "through improvements in air management, combustion, oil consumption control, and fuel injection."25 "When compared to emissions from unregulated engines in the early 1970s, today's on-highway diesel engines emit [ninety-nine] percent less PM and $\mathrm{NO}_{\mathrm{x}},{ }^{, 26}$

13. See U.S. ENVTL. Prot. AgenCy ET AL., INTERIM JoINT TEChNICAL ASSESSMENT REPORT: Light-Duty Vehicle Greenhouse Gas Emission Standards and Corporate AVERage Fuel ECONOMY STANDARDS FOR MODEL YEARS 2017-2025 ch. 3 at 1, 21 (2010), available at www.epa.gov/otaq/climate/regulations/ldv-ghg-tar.pdf.

14. Charles RIVER Assocs., supra note 11, at 2.

15. Id. at 31-33.

16. Id. at $9-11$.

17. Id. at $36-40$.

18. Id. at $22-28$.

19. Id. at 80 .

20. Id. at 15-18.

21. Id. at 12-15.

22. Technology Guide: Paper Abstracts, DIESELNET, http://www.dieselnet.com/ tginfo/abstracts.html (last visited Apr. 10, 2012).

23. Id.

24. Id.

25. Id.

26. CUMmins InC., Sustainability REPORT 22 (2010), available at http://www.cummins.com/cmiweb/attachments/public/About\%20Cummins/ Sustainability\%20Report/Cummins_2010_SustainabilityReport_FULL.pdf.zip. 


\section{B. How Diesels Are Regulated}

Diesel engine regulations for mobile sources can be divided into three categories: those of first adopters, second adopters, and unregulated countries. ${ }^{27}$ First adopters set their own emission standards and consist of the United States of America, the European Union, Japan, and the International Maritime Organization (IMO), a division of the United Nations. ${ }^{28}$ The world's remaining countries are either second adopters or unregulated countries. ${ }^{29}$ Second adopters accept a first adopter's products into their respective countries and generally implement first adopter regulations in whole or in part. ${ }^{30}$ This practice can be a cost-effective means of obtaining regulated products in a given market. ${ }^{31}$ Second adopter countries include Australia, Brazil, China, India, Mexico, and South Korea. ${ }^{32}$ An unregulated country accepts any diesel product, without regard to the amount of pollution it emits, ${ }^{33}$ and diesel exhaust emissions are highest in these nations. ${ }^{34}$

\section{First Adopters}

First adopters have been regulating mobile sources for several decades, but the regulation of diesel emissions has increased sharply over the past ten years. The United States began regulating mobile sources with the passage of the Clean Air Act of $1970 .{ }^{35}$ The EPA next began regulating diesel mobile sources for on-highway trucks in $1985 .{ }^{36}$ After twenty years of highway mobile source regulation and increasingly costly controls on the automotive industry, Congress recognized that a considerable amount of pollution comes from

27. See supra note 9 and accompanying text.

28. Interview with Rich S. Wagner, Emissions Certification \& Compliance Director, Cummins Inc., in Columbus, Ind. (Oct. 18, 2010); U.N. Dep't of Econ. \& Soc. Affairs, supra note 8, sec. 64; see infra notes 48-55 and accompanying text (discussing IMO standards).

29. Interview with Robert Jorgensen, supra note 9.

30. Id.

31. See Technical Information on Technical Barriers to Trade, WoRLD TRADE ORG., http://www.wto.org/english/tratop_e/tbt_e/tbt_info_e.htm (last visited May 4, 2012).

32. Interview with Rich S. Wagner, supra note 28 . This is not an exhaustive list and serves as an illustration for the increase in countries adopting their own unique requirements for certified products. See Emission Standards, DiESELNET, http://www.dieselnet.com/standards/ (last visited May 21, 2012) (providing a summary of worldwide diesel emissions standards).

33. Interview with Rich S. Wagner, supra note 28.

34. Id.

35. U.S. Envtl. Prot. Agency, Milestones in Auto Emissions Control 1 (1994), available at www.epa.gov/oms/consumer/12-miles.pdf; Clean Air Act of 1970, 42 U.S.C. $\S$ 7401.

36. U.S. ENVTL. PROT. AGENCY, supra note 35, at 2; Emission Standards for 1991 and Later Model Year Diesel Heavy-Duty Engines, 50 Fed. Reg. 10,653 (Mar. 15, 1985) (codified at 40 C.F.R. pt. 86); Emission Standards for 1994 and Later Model Year Diesel Heavy-Duty Engines and Vehicles, 50 Fed. Reg. 10,654 (Mar. 15, 1985) (codified at 40 C.F.R. pt. 86). 
nonroad sources and asked the EPA to quantify those unregulated emissions. ${ }^{37}$ The EPA adopted nonroad source regulation in $1994^{38}$ and, by 2000 , had turned its attention to regulating marine ${ }^{39}$ and locomotive engines. ${ }^{40}$

The European Union began regulating mobile sources in $1988,{ }^{41}$ followed by heavy-duty trucks in $1992^{42}$ and non-road engines in $1997 .{ }^{43}$ Unlike EPA regulations, "[European Union] regulations introduce different emission limits for compression ignition (diesel) and positive ignition (gasoline, NG, LPG, ethanol, $[\ldots])$ vehicles. Diesels have more stringent $\mathrm{CO}$ standards but are allowed higher $\mathrm{NO}_{\mathrm{x}}$."

Japan began regulating diesel passenger cars in $1986 .^{45}$ These regulations, however, did not become stringent until 2005, when off-road engine regulations were added. ${ }^{46}$ Japan also has regulations to reduce emissions from older vehicles currently in-use, either through requirements for fleets to upgrade to newer model vehicles or requirements to retrofit vehicles with devices to reduce emissions. $^{47}$

The IMO is a relative newcomer to the first adopter group for diesel exhaust emissions but has made a significant impact on reducing pollution from marine vessels throughout the globe. ${ }^{48}$ "Oil pollution of the seas was recognized

37. U.S. Envtl. Prot. Agency, Nonroad Engine and Vehicle Emission StudyREPORT, at v (1991) available at www.epa.gov/nonroad/nrstudy.pdf.

38. Determination of Significance for Nonroad Sources and Emission Standards for New Nonroad Compression-Ignition Engines at or Above 37 Kilowatts, 59 Fed. Reg. 31,306 (June 17, 1994) (codified at 40 C.F.R. pt. 89).

39. Emission Standards, United States, Marine Diesel Engines, DIESELNET, http://www.dieselnet.com/standards/us/marine.php (last updated Aug. 2011); Control of Emissions from Marine Compression-Ignition Engines, 64 Fed. Reg. 73,331 (Dec. 29, 1999) (codified at 40 C.F.R. pt. 94).

40. Emission Standards, United States, Locomotives, DIESELNET, http://www.dieselnet.com/standards/us/loco.php (last updated April 2008). Control of Air Pollution from Locomotives and Locomotive Engines, 63 Fed. Reg. 18,998 (Apr. 16, 1998) (codified in 40 C.F.R. pt. 92).

41. Council Directive 88/76/EEC, art. 2, 1987 O.J. (L 36) 1, available at http://eurlex.europa.eu/LexUriServ/LexUriServ.do?uri=CELEX:31988L0076:en:NOT.

42. Emission Standards, Europe, Heavy-Duty Diesel Truck and Bus Engines, DIESELNET, http://dieselnet.com/standards/eu/hd.php (last visited May 8, 2012).

43. Emission Standards, Europe, Nonraod Diesel Engines, DIESELNET, http://dieselnet.com/standards/eu/nonroad.php (last visited May 8, 2012).

44. Emission Standards, Europe, Cars and Light Trucks, DIESELNET, http://www.dieselnet.com/standards/eu/ld.php\#stds (last visited Apr. 10, 2012); see Emission Standards, Europe, Nonroad Diesel Engines, DIESELNET, http://www.dieselnet.com/ standards/eu/nonroad.php (last visited May 8, 2012).

45. Emission Standards, Japan, DIESELNET, http://www.dieselnet.com/standards/jp/ (last visited May 8, 2012).

46. Id.

47. Id.

48. In the case of U.S. commercial marine products, IMO is a second adopter because the EPA has had its own regulations for commercial marine products since 2004. Diesel Boats and 
as a problem in the first half of the 20th century[,] and various countries introduced national regulations to control discharges of oil within their territorial waters. ${ }^{, 49}$ Realizing that oil pollution was an international concern, the United Kingdom organized a conference on oil pollution in $1954 .^{50}$ The conference culminated in the adoption of the International Convention for the Prevention of Pollution of the Sea by Oil (OILPOL), ${ }^{51}$ which was transferred to the IMO in $1958 .{ }^{52}$

The IMO has since developed regulations, known as "annexes," 53 that address various types of pollution. ${ }^{54}$ Most notably, in September 1997 the IMO adopted MARPOL Annex VI: Prevention of Air Pollution from Ships. ${ }^{55}$ This regulation establishes limits on sulfur oxide and nitrogen oxide emissions from ship exhausts and prohibits deliberate emissions of ozone depleting substances. ${ }^{56}$ The IMO is unique from other first adopters in that it does not implement its regulations. ${ }^{57}$ Rather, a country may choose to adopt and enforce an IMO regulation under that country's sovereign laws. ${ }^{58}$ Of the one hundred sixty-three IMO member countries, ${ }^{59}$ sixty-one have ratified MARPOL Annex $V I$, representing almost eighty-five percent of the world's shipping tonnage. ${ }^{60}$

Ships, U.S. ENVTL. Prot. AGENCY, http://www.epa.gov/oms/marine.htm (last updated June 29, 2011); see Control of Emissions from Marine Compression-Ignition Engines, 40 C.F.R. $\S$ 94.8(a)(1) (2007).

49. OSPAR COMM'N, BACKGROUND DOCUMENT ON THE ECOLOGICAL QUALITY OBJECTIVE ON OILED GUILLEMOTS 6 (2005).

50. Id.

51. Id.

52. Id.; The Origins of the International Maritime Organization, INT'L MAR. ORG., http://www.imo.org/KnowledgeCentre/ReferencesAndArchives/Pages/TheOriginsOfIMO.aspx (last visited Apr. 15, 2012) ("The conference agreed that IMO would assume responsibilities for the convention as soon as the IMO Convention entered into force.").

53. See International Convention for the Prevention of Pollution from Ships (MARPOL), INT'L MAR. ORG., http://www.imo.org/about/conventions/listofconventions/pages/internationalconvention-for-the-prevention-of-pollution-from-ships-(marpol).aspx (last visited Apr. 15, 2012).

54. See Conventions, INT'L MAR. ORG., http://www.imo.org/About/Conventions/ Pages/Home.aspx (last visited Apr. 14, 2012).

55. Int'l Mar. Org., Protocol of 1997 to Amend the International Convention for the Prevention of Pollution from Ships, 1973, as Modified by the Protocol of 1978 Relating Thereto, Sept. 26, 1997, available at http://www.admiraltylawguide.com/conven/ protomarpol1997.html.

56. Prevention of Air Pollution from Ships, INT'L MAR. ORG., http://www.imo.org/ blast/mainframe.asp?topic_id=233 (last visited Apr. 10, 2012). In October 2008 the IMO added a Tier III standard, which further regulates harmful emissions from ships. Id.

57. Frequently Asked Questions, How Does IMO Implement Legislation?, INT'L MAR. ORG., http://www.imo.org/About/Pages/FAQs.aspx (last visited Apr. 10, 2012).

58. Id.

59. See Status of Conventions, INT'L MAR. ORG., http://www.imo.org/About/ Conventions/StatusOfConventions/Documents/status-X.xls (last updated Mar. 31, 2012).

60. See id. The United States ratified MARPOL Annex VI in October 2008. See Press Briefing 44, Int'l Mar. Org., USA Ratifies International Rules on Air Pollution from Ships (Oct. 


\section{Second Adopters}

Second adopters present the most significant challenge to a global company wanting to offer its products worldwide. Some second adopters accept a first adopter's certified product without modifying the first adopter's regulatory requirements, ${ }^{61}$ others create additional requirements, such as product modifications and supplementary reporting or testing. ${ }^{62}$ For comparison: Australia indiscriminately accepts U.S., European Union, or Japanese certified engines; ${ }^{63} \mathrm{China}$, on the other hand, has adopted European Union-type regulations but requires that engines undergo independent Chinese testing and certification procedures. ${ }^{64}$ China also has different regulatory standards for different areas within the country. ${ }^{65}$ "Large metropolitan areas, including Beijing and Shanghai, have adopted more stringent regulations on an accelerated schedule .....

Similarly, South Korea implements European Union-type regulations but requires that engines be tested locally ${ }^{67}$ Thus, a product already certified by a European Union-approved testing agency and accepted into European Union countries must be re-tested. ${ }^{68}$ Because of engine and test cell variability, seemingly identical engine tests may produce dissimilar results when conducted at different facilities. ${ }^{69}$ As a consequence, previously tested products that certify close to the EU regulatory emissions limit may be barred from South Korean importation. $^{70}$

Compliance with the unique regulatory requirements of each second adopter country can result in expensive burdens on global manufacturers. ${ }^{71}$

9, 2008), available at http://www.imo.org/MediaCentre/PressBriefings/Archives/Pages/ 2008.aspx (select "15" hyperlink to expand archive).

61. ASIF Faiz, Air POLLUTION FROM Motor Vehicles: STANDARDS AND TECHNOLOGIES FOR Controlling Emissions 1, 9-21 (1996).

62. Id.

63. See Vehicle Standard (Australian Design Rule 80/03 - Emission Control for Heavy Vehicles) 2006 (Cth) ss 5.1-5.2 (Austl.).

64. Interview with Rich S. Wagner, supra note 28; Emissions Standards, China, DIESELNET, http://www.dieselnet.com/standards/cn/ (last updated Nov. 2011); see Law of the People's Republic of China on the Prevention and Control of Atmospheric Pollution (promulgated by the President of the People's Republic of China, Apr. 29, 2000, effective Sept. 1, 2000), available at http://english.mep.gov.cn/Policies_Regulations/ laws/environmental_laws/200710/t20071009_109943.htm.

65. Emissions Standards, China, supra note 64. "In addition to National Standards, which are mandatory nationwide, Environmental Standards may apply to industries that have an impact on the quality of the environment, and Local Standards may be issued by local governments." Id.

66. Id.

67. Interview with Rich S. Wagner, supra note 28.

68. Id.

69. Id.

70. Id.

71. Technical Information on Technical Barriers to Trade, supra note 31. 
These requirements serve as an effective trade barrier ${ }^{72}$ and, frustratingly, do not lead to a commensurate reduction in diesel exhaust emissions. ${ }^{73}$. In some cases, a second adopter's added requirements may even cause more environmental harm by increasing transaction costs to the point of preventing a global company with superior emission technology from competitively entering that second adopter market. ${ }^{74}$ Ironically, the transaction costs to tailor a product for compliance with varying second adopter standards may be so high that an unregulated country, which does not require diesel products with any emission standard, could achieve more cost-effective pollution control than a second adopter. $^{75}$

\section{The ENVIRONMENTAL PROBLEM}

"The World Health Organization estimates that urban air pollution contributes to approximately 800,000 deaths and 6.4 million lost life-years worldwide each year...."

Air pollution from combustion sources is associated with a broad spectrum of acute and chronic health effects, that may vary with the pollutant constituents. Particulate air pollution (i.e. particles small enough to be inhaled into the lung,) is consistently and independently related to the most serious effects, including lung cancer and other cardiopulmonary mortality. Other constituents, such as lead and ozone, are also associated with serious health effects, and contribute to the burden of disease attributable to urban air pollution. ${ }^{77}$

Worse yet, children may suffer more than adults from the effects of diesel

72. Id.; see also Mark Drajem, U.S. Said to Ask Korea to Accept Auto Standards to Advance Free-Trade Pact, BLOOMBERG (Oct. 29, 2010), http://www.bloomberg.com/ news/2010-10-29/u-s-said-to-ask-korea-to-accept-auto-standards-to-advance-free-tradepact.html? cmpid=yhoo.

73. Interview with Robert Jorgensen, supra note 9.

74. See Technical Information on Technical Barriers to Trade, supra note 31.

75. For example, suppose a second adopter's added requirements create $\$ 100$ USD in added product costs but do not reduce the emissions output of the engine. Contrast this with an unregulated country that accepts any diesel product, including the same product for which the second adopter added $\$ 100$ to the product cost. Thus, the unregulated country is receiving the same emissions output without the added $\$ 100$ in product costs and has achieved a more costeffective solution.

76. Sumi Mehta et al., Commentary, Public Health and Air Pollution in Chinese Cities: Local Research with Global Relevance, 10 CHINA ENV'T SERIES 65, 65 (2009), available at http://www.healtheffects.org/International/CES10.pdf\#HEI\%20 Commentary.

77. WORLD HEALTH ORG., THE WORLD HEALtH REPORT 2002, at 68-69 (2002), available at http://www.who.int/entity/whr/2002/en/whr02_en.pdf. 
exhaust pollution. An increased frequency of childhood illness has been associated with air pollution, likely because "[children] breathe [fifty] percent more air per pound of body weight than do adults."78

In addition to its negative health consequences, air pollution specifically from diesel powered engines or equipment has negative environmental effects. Ozone reduces yield for both commercial and noncommercial vegetation and is a contributing factor of acid rain. ${ }^{79} \mathrm{NO}_{\mathrm{x}}$ deposits also stimulate algae growth in fragile coastal ecosystems. ${ }^{80}$

\section{A. Air Pollution Is a Global Problem Addressed Regionally}

The social and environmental burdens resulting from diesel exhaust emissions "predominantly occur[] in developing countries." construction equipment and electric generators often are higher polluters than those used in on-highway trucks and buses, ${ }^{82}$ and they are more prevalent in developing countries than in developed ones. ${ }^{83}$ Developed countries typically have fewer construction projects and more established power generation facilities. $^{84}$

Those countries without diesel exhaust emission standards, or those with ineffective regulations, must absorb the high social costs of poor air quality. ${ }^{85}$ Examining the current status of air quality in some second adopter countries indicates that the incremental costs of added regulatory requirements may not outweigh the benefits of modifying a first adopter's regulation. In fact, despite having air pollution regulations, many second adopter countries still have poor air quality ${ }^{86}$ Consider the following information on China, India, and Mexico.

\section{China}

Urban air pollution accounts for over 500,000 deaths and 4.2 million lost

78. See U.S. Envtl. Prot. Agency, What You Should Know About Diesel Exhaust AND SCHOOL BUS IDLING (2003), available at www.epa.gov/cleandiesel/documents/ 420f03021.pdf.

79. Id.

80. U.S. Envtl. Prot. Agency, Final Regulatory Impact analysis: Control of EMISSIONS FROM MARINE DIESEL ENGINES 98 (1999), available at www.epa.gov' oms/regs/nonroad/marine/ci/fr/ria.pdf.

81. WORLD HEALTH ORG., supra note 77, at 69.

82. Id.

83. Interview with Rich S. Wagner, supra note 28.

84. Id.

85. Id.

86. OECD, Environmental Performance Review of China 4 (2006), available at www.oecd.org/dataoecd/58/23/37657409.pdf. [hereinafter OECD, CHINA]; OECD, ENVIRONMENTAL COMPLIANCE AND ENFORCEMENT IN INDIA: RAPID ASSESSMENT 7 (2006), available at www.oecd.org/dataoecd/39/27/37838061.pdf [hereinafter OECD, INDIA]. 
life-years annually in China and other "rapidly urbanizing" Asian countries. ${ }^{87}$ With its growing economy, China continues to experience increased industrialization, urbanization, and vehicularization. ${ }^{88}$ "[M]otor vehicle traffic already represents the [country's] largest source of urban air pollution," and "vehicle numbers doubled in the five years up to $2000 . " 89$ In addition, urban transportation and bicycle use are on the decline. ${ }^{90}$ Add in the high sulfur content of China's available vehicle fuels" and it is easy to understand why "air quality in some Chinese cities remains among the worst in the world[,] $]^{92}$ and China shows no signs of scaling back its economic expansion. ${ }^{93}$

Fortunately, an increasing number of government decision-makers, businesses, and citizens are raising concerns about the health impacts of urban air pollution from the rapid development of many Asian cities and industrial areas. ${ }^{94}$ Intergovernmental organizations are also speaking out. In 2006 the Organisation for Economic Co-operation and Development (OECD), a forum of thirty democratic countries that "work together to address the economic, social, and environmental challenges of globalisation," some cases, China's environmental laws and regulations are inconsistent, concealed, and discriminatory. ${ }^{96}$ To address these issues, the OECD offered China the following recommendations:

The Chinese authorities should launch a review of environmental legislation to eliminate important discrepancies

87. Mehta et al., supra note 76 , at 65 .

88. Id.

89. OECD, CHINA, supra note 86, at 5 (emphasis omitted).

90. Id.

91. Id.

92. Id. at 4 .

93. Kong Chiu et al., Commentary, Breathing Better: Linking Energy and GHG Reduction to Health Benefits in China, 9 CHINA ENV'T SERIES 117, 122 (2007), available at http://www.wilsoncenter.org/topics/pubs/ces9.pdf. "China's rapid expansion is expected to continue in the immediate future, with the National Congress establishing a goal of fourfold economic growth between 2000 and 2020 . While the economy remains heavily industrialized and dependent on fossil fuels, China's GHG emissions also will continue to grow." Id.

94. Mehta et al., supra note 76, at 65-66.

95. OECD, ENVIRONMENTAL COMPLIANCE AND ENFORCEMENT IN CHINA 2 (2006), available at www.oecd.org/dataoecd/33/5/37867511.pdf. The OECD "help[s] governments respond to new developments and concerns, such as corporate governance, the information economy, and the challenges of an ageing population." Id. The OECD also "provides a setting where governments can compare policy experiences, seek answers to common problems, identify good practice, and work to co-ordinate domestic and international policies." Id. "The OECD Member countries are: Australia, Austria, Belgium, Canada, the Czech Republic, Denmark, Finland, France, Germany, Greece, Hungary, Iceland, Ireland, Italy, Japan, Korea, Luxembourg, Mexico, the Netherlands, New Zealand, Norway, Poland, Portugal, the Slovak Republic, Spain, Sweden, Switzerland, Turkey, the United Kingdom, and the United States." Id.

96. Id. at 7. 
and gaps between the principal laws and executive regulations. The legislative and rule-making processes should be made more transparent to build better relations between regulating entities, the regulated community and the public. Allowing more public participation in the regulatory process at all stages, from drafting environmental legislation to enforcement activities, can help improve policy effectiveness and address potential inconsistencies early in the legislative process. $^{97}$

This Note argues that these changes might not be necessary if global regulations were adopted for diesel exhaust emissions.

\section{India}

In India, industrial growth, economic development, and urbanization are "causing severe environmental problems that have local, regional and global significance." "98 "[A]mbient levels of air pollutants [in India's major cities] exceed both the World Health Organization and Indian standards, particularly for particulate matter. Of the total air pollution load nationwide, vehicular sources contribute 64 percent, thermal power plants 16 percent, industries 13 percent, and the domestic sector 7 percent." 99 Further, "[i]t is estimated that over 96 percent of India's total demand for commercial energy is met by fossil fuel with coal contributing 60 percent and petroleum products providing the remaining 36 percent." 100 Empirical evidence also shows that India's urban areas are still trending upward in $\mathrm{PM}$ and $\mathrm{NO}_{\mathrm{x}}$ levels because of economic growth. ${ }^{101}$ Despite a strong policy and an institutional framework, ${ }^{102}$ environmental degradation continues in many areas, resulting in growing dissatisfaction among the Indian public. ${ }^{103}$

One environmental study conducted in Hyderabad, India, found mobile source emissions to be "the largest sector of GHG and air pollutants in [the city]," accounting for "approximately [63 percent] of total emissions in 2001."104 If the Indian government fails to address this issue, the study

97. $I d$.

98. OECD, INDIA, supra note 86 , at 7 .

99. Id.

100. Id.

101. THE WORLD BANK, INDIA: STRENGTHENING INSTITUTIONS FOR SUSTANABLE GROWTH 10 (2006), available at http://siteresources.worldbank.org/INDIAEXTN/Resources/2955831169456822314/India_CEA_Report_FINAL_Dec.pdf.

102. Id. at 31 .

103. Id. at 12 .

104. ENV'T Prot. TRAINING \& RESEARCH Inst., InTEGRATEd ENVIRONMENTAL STRATEgIES (IES) STUDY FOR CITY OF HYDERABAD, INDIA 4 (2005), available at http://eptri.com/ files/INTEGRATED-ENV-STRATEGIES.pdf. 
predicted, mobile source emissions would contribute up to 75 percent by $2021 .{ }^{105}$ The study concluded that "implementing reduction measures within [India's] transportation sector would prevent an estimated 2,000 to 20,000 deaths from long-term exposure to $\mathrm{PM}_{10}$ concentrations and 1,500 to 7,500 deaths from short-term exposure to $\mathrm{PM}_{10}$ concentration in 2011 and 2021 respectively." 106 The study also considered the financial savings that could result from a reduction in mobile source pollution and found that implementing effective transportation solutions could save up to $\$ 1,208$ million (US) a year from avoided mortality by 2021 , and up to $\$ 506$ million (US) a year from avoided cardiovascular and respiratory diseases. ${ }^{107}$

\section{Mexico}

Mexico also faces difficult challenges with air pollution. "Due to complex socio-political, economic and geographical realities, Mexico City suffers from one of the worst air pollution problems in the world." 108 "With nearly 20 million inhabitants, 3.5 million vehicles, and 35,000 industries, Mexico City consumes more than 40 million liters of fuel each day."109 Complicating matters, the city has poor ventilation because of its location in a closed basin high above sea level. ${ }^{110}$ "The combination of these and other factors has led to a serious air quality problem. In 2002, Mexico City air quality exceeded local standards for ozone (110 ppb for 1 hour) on $80 \%$ of the days of the year." 111 Mexico City's greenhouse gas emissions are also troublesome. ${ }^{112}$ In 1998 Mexico was the thirteenth largest GHG producing nation in the world, ${ }^{113}$ and Mexico City alone accounted for approximately 13 percent of the country's total. ${ }^{114}$

Like China and India, however, Mexico is not without opportunities to improve its air quality. The OECD has offered several suggestions. Mexico must strengthen the implementation and enforcement of its air emissions regulatory system as well as its "integration of air quality concerns in the

105. Id.

106. Id. at 7.

107. Id.

108. Galen McKinley et al., The Local Benefits of Global Air Pollution Control in MEXICo CITY 6 (2003), available at http://www.globalcitizen.net/Data/Pages/2929/ papers/2010020110947302.pdf.

109. Id.

110. Sergio Bernal-Salazar et al., Impact of Air Pollution on Ring Width and Tracheid Dimensions in Abies Religiosa in the Mexico City Basin, 25 INT'L Assoc. WoOD ANATOMISTS J. 205, 205 (2004).

111. MCKINLEY ET AL, supra note 108.

112. Id.

113. Id.

114. Id. 
industry, transport[ation] and energy sectors.",115 This can be accomplished both by adopting certain "economic instruments [and by] eliminat [ing] ... subsidies with harmful environmental effects." 116 Mexico also must continue to improve fuel quality, focusing particularly on the reduction of sulfur in diesel and gasoline products. ${ }^{117}$

In response to developing nations' struggles to obtain clean air without stifling their growing economies, the EPA created the Integrated Environmental Strategies (IES) program. ${ }^{118}$ "The program encourages developing countries to analyze and implement policy, technology, and infrastructure measures with multiple public health, economic, and environmental benefits." ${ }^{119}$ It focuses on helping developing countries reduce air pollution through economic analysis and the creation of programs that reduce the production of greenhouse gases. ${ }^{120}$ Thus far, Argentina, Brazil, Chile, China, India, Mexico, the Philippines, and the Republic of Korea have benefitted from IES; $;{ }^{121}$ however, scant evidence exists to support the notion that these countries consider the benefits of a more international approach to regulation for diesel exhaust emissions. ${ }^{122}$ In conjunction with these second adopter countries, the EPA has conducted significant studies of air pollution in major cities across the globe, but in order to achieve significant improvements in air quality, its international work must continue. A global diesel exhaust emission regulation could simplify and propel these efforts.

\section{B. Countries Can Address Global Warming Before Addressing Air Quality}

With the world moving toward the regulation of greenhouse gas emissions, ${ }^{123}$ another environmental concern has developed as a result of the inverse relationship between $\mathrm{CO}_{2}$ and $\mathrm{NO}_{\mathrm{x}}$ emissions. ${ }^{124}$ Over the past several

115. OeCD, Environmental Performance Review of MeXico 4 (2003), available at www.oecd.org/dataoecd/33/33/18385233.pdf.

116. Id.

117. $I d$.

118. Integrated Environmental Strategies, U.S. ENVTL. Prot. AGENCY, http://www.epa.gov/ies/basicinfo.htm (last updated June 3, 2009).

119. Id.

120. Id

121. Id.

122. Peter H. Sand, Lessons Learned in Global Environmental Governance, 18 B.C. ENVTL. AFF. L. REV. 213, 256 (1991).

123. See, e.g., Press Release, supra note 7; see also, e.g., Proposal for a Regulation of the European Parliament and of the Council Setting Emission Performance Standards for New Passenger Cars as Part of the Community's Integrated Approach to Reduce CO2 Emissions from Light-duty Vehicles, COM (2007) 856 final (Dec. 19, 2007), available at http://eurlex.europa.eu/LexUriServ/LexUriServ.do?uri=CELEX:52007PC0856:EN:NOT.

124. Philippe Crist, OECD, Greenhouse Gas Emissions Reduction Potential from INTERNATIONAL SHIPPING 24 (2009) (discussing $\mathrm{CO} 2$ and NOx in the context of marine vessel engines). 
decades, diesel engine and equipment manufacturers have been retarding engine injection timing in order to meet the EPA's $\mathrm{NO}_{x}$ emission standards. ${ }^{125}$ This process reduces $\mathrm{NO}_{\mathrm{x}}$ but also reduces an engine's fuel efficiency. ${ }^{126}$ Conversely, as an engine's fuel efficiency improves, $\mathrm{CO}_{2}$ emissions are reduced. ${ }^{127}$ Because $\mathrm{CO}_{2}$ production is proportional to an engine's fuel efficiency, the reduction in $\mathrm{NO}_{\mathrm{x}}$ emissions has caused unregulated $\mathrm{CO}_{2}$ production to increase over time (see Table 1). Thus, when $\mathrm{CO}_{2}$ is regulated, global automotive companies will strive to maximize engine efficiency in order to reduce $\mathrm{CO}_{2}$ emissions. ${ }^{128}$ Just as retarding injection timing reduces $\mathrm{NO}_{\mathrm{x}}$ emissions, advancing an engine's timing so that fuel is injected sooner in the engine's compression stroke improves fuel efficiency; which, consequently, produces higher $\mathrm{NO}_{\mathrm{x}}$ emissions. ${ }^{129}$

Table 1: Interaction Between Reduced $\mathrm{NO}_{\mathrm{x}}$ and $\mathrm{CO}_{2}{ }^{130}$

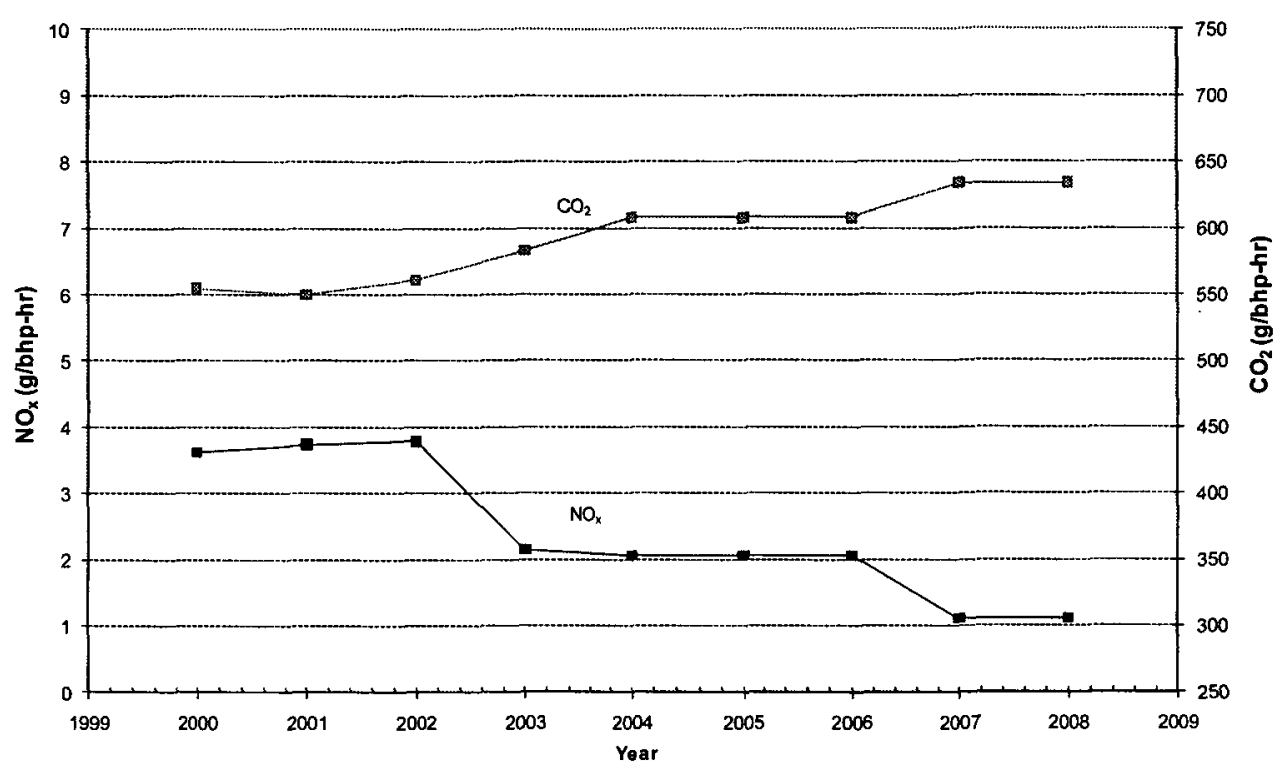

The interplay between $\mathrm{NO}_{\mathrm{x}}$ and $\mathrm{CO}_{2}$ emissions will become critical as more countries consider adopting greenhouse emission regulations. If a country

125. Interview with Robert Jorgensen, supra note 9.

126. Id.

127. Id.

128. Interview with Rich S. Wagner, supra note 28; U.S. ENVTL. PROT. AGENCY, LIGHTDUTY Automotive TeCHNOLOGY, CARBON DIOXIDE EMISSIONS, AND FUEL ECONOMY TRENDS: 1975 THROUGH 2011, at iv (2012), available at http://www.epa.gov/otaq/cert/mpg/ fetrends/2012/420s12001a.pdf.

129. Interview with Robert Jorgensen, supra note 9; Interview with Rich S. Wagner, supra note 28.

130. Graph is for representational purposes; data are available at http://www.epa.gov/ otaq/certdata.htm\#largeng. 
adopts a $\mathrm{CO}_{2}$ standard but does not adopt a $\mathrm{NO}_{\mathrm{x}}$ standard, global companies may make product line changes to increase fuel efficiency, and the trade-off could be an increase in higher $\mathrm{NO}_{\mathrm{x}}$-emitting engines. ${ }^{131}$ Diesel engine manufacturers already focus on fuel economy because of customer demand, particularly manufacturers of on-highway truck engines. ${ }^{132}$ Diesel technology is the dominant power choice in the U.S. trucking industry because fuel costs go directly to a trucking company's bottom line, and the use of light duty diesels may soon follow suit. ${ }^{133}$ As of Model Year 2010, relatively few diesel powered light duty vehicles existed in North America. ${ }^{134}$ However, in its 2010 Technical Assessment Report on greenhouse gasses, the EPA noted that a few automotive companies believe diesel technology will be an important addition to their future U.S. product offerings, and that these companies are pursuing the use of diesel in the 2017 to 2025 timeframe to improve fuel economy and reduce $\mathrm{CO}_{2}$ emissions. ${ }^{135}$ Thus, the use of higher $\mathrm{NO}_{\mathrm{x}}$-emitting diesel engines is likely to grow in the near future with companies relying on diesel aftertreatment devices to meet current $\mathrm{NO}_{\mathrm{x}}$ emission levels. ${ }^{136}$

A diesel engine's increased $\mathrm{NO}_{\mathrm{x}}$ output may not be an issue in first or second adopter countries that currently regulate $\mathrm{NO}_{\mathrm{x}}$ emissions because, there, engine manufactures would be forced to "clean up" the increased $\mathrm{NO}_{\mathrm{x}}$ through the use of diesel aftertreatment technology. ${ }^{137}$ Emissions can be treated with a $\mathrm{NO}_{\mathrm{x}}$ adsorption catalyst system or a urea/ammonia selective catalytic reduction (SCR) system. ${ }^{138}$ These methods can control $\mathrm{NO}_{\mathrm{x}}$ emissions during lean (excess air) operation to achieve the low $\mathrm{NO}_{\mathrm{x}}$ emission levels while allowing a diesel engine manufacturer to advance an engine's timing and maximize its fuel efficiency. ${ }^{139}$ The stringent $\mathrm{NO}_{\mathrm{x}}$ emission standards in the United States and Europe mandate the use of such diesel technology enablers. ${ }^{140}$ All U.S. on-

131. See supra notes $123-27$ and accompanying text.

132. Interview with Rich S. Wagner, supra note 28.

133. Id.

134. The Consumer Guide to 2010 Diesel Vehicles, 2010 Diesel-Powered Vehicle Lineup, CONSUMER GUIDE, http://consumerguideauto.howstuffworks.com/2010-diesel-vehicle-buyingguide1.htm (last visited Apr. 20, 2012). Eleven diesel-powered light-duty passenger vehicles were available in 2010 from only four companies: Volkswagen, BMW, Mercedes, and Audi. Id. They are the Audi A3 and Q7; BMW 3 series and X5; Mercedes-Benz E-Class, M-Class, RClass, and GL; and Volkswagen Golf, Jetta, and Touareg. Id. Note that all manufacturers are German.

135. See U.S. ENVTL. Prot. AgENCY ET AL., supra note 13, ch. 3 at 1, 21.

136. Interview with Robert Jorgensen, supra note 9.

137. Worldwide Emissions Regulations, Cummins INC., http://cumminsemissionsolutions.com/ces/navigationAction.do?url=SiteContent+en+HTML+E missionsTechnology+Worldwide_Emissions_Regualtions (last visited May 21, 2012).

138. U.S. ENVTL. PROT. AGENCY ET AL., supra note 13, ch. 3 at 21.

139. How Selective Catalytic Reduction (SCR) Works, DISCOVERDEF.COM, $\mathrm{http}: / / \mathrm{www}$.discoverdef.com/def-overview/selective-catalytic-reduction/ (last visited Apr. 15, 2012).

140. Worldwide Emissions Regulations, supra note 137. 
highway truck and engine manufacturers, with one exception, have chosen SCR as their emissions solution, ${ }^{141}$ and most Model Year 2010 or newer on-highway trucks employ SCR as a means to chemically treat the exhaust emissions of an engine after the combustion process. ${ }^{142}$

One of the drawbacks of SCR technology is that it costs up to $\$ 12,000$ per system. ${ }^{143}$ Because of this additional cost, manufacturers may put fuel efficiency design improvements in place for unregulated countries without including aftertreatment technology. ${ }^{144}$ Another disadvantage of SCR is the requirement that urea must be injected into the exhaust for the purpose of creating a chemical reaction to reduce $\mathrm{NO}_{\mathrm{x}}{ }^{145}$ Thus, a global solution that uses urea would require a global infrastructure in which urea can be made readily available. In other words, a company could offer two identical fuel efficient engine systems: one with an aftertreatment catalyst for a regulated market and another without the aftertreatment catalyst for an unregulated market. Consequently, without a global diesel exhaust emission regulation, the global $\mathrm{NO}_{\mathrm{x}}$ level can be expected to increase. ${ }^{146}$

\section{BARRIERS PREVENTING A GLOBAL DIESEl EXHAUST EMISSION REGULATION}

Recognizing that no international governing agency exists to create a binding global regulation, ${ }^{147}$ a global diesel exhaust emissions standard would need to be created and adopted voluntarily by independent countries, much like IMO's Annex VI. ${ }^{148}$ Competing concerns exist, however, which have so far prevented the adoption of an international regulation.

\section{A. Trade Barrier Protection}

One reason that a global diesel emission standard has not yet been adopted is that regulations are an effective means to achieve trade barrier

141. Steve Sturgess, EPA, CARB Workshop Examines Driver Defeat of SCR Engines, TRUCKINGINFO (July 22, 2010), http://www.truckinginfo.com/news/newsdetail.asp?news_id $=71106$.

142. Frequently Asked Questions, DisCOVERDEF.COM, http://www.discoverdef.com/defoverview/faq/ (last visited Apr. 15, 2012).

143. Sean Kilcarr, Price Point, FleEtOWner (Aug. 1, 2009), http://fleetowner.com/ trucking_regulations/price_point_0809/.

144. See supra notes $123-27$ and accompanying text.

145. Steve Sturgess, supra note 141.

146. See supra Part III.B.

147. See International Law, WORLD HEALTH ORG., http://www.who.int/trade/glossary/ story061/en/index.html (last visited May 21, 2012).

148. See supra notes 52-60 and accompanying text. 
protection. ${ }^{149}$ Although most environmental regulations are enacted to protect the health and welfare of the public, this is not considered their main purpose under a public choice theory of economics. ${ }^{150}$ Public choice theory holds that "legislatures represent the interests of other parties, not [the interests] of the public." 151 Thus, politicians in a given country primarily respond to the concerns of existing engine manufacturers. These concerns typically arise in two scenarios. First, situations could exist where manufacturers already doing business in a country do not want a new regulation because it will increase production costs. ${ }^{152}$ If production costs increase, and the manufacturer cannot pass those costs on to the consumer, then the company's profit will suffer. ${ }^{153}$ This theory presumes that manufacturers want to avoid all regulations because of product cost increases; however, it should be noted that a regulation may benefit those manufacturers that find themselves already in compliance with a newly imposed standard. ${ }^{154}$

The second situation occurs where a manufacturer already doing business in a market wants the country to adopt a regulation as a form of trade barrier protection, making it cost-prohibitive for potential competitors to enter that market. ${ }^{155}$ In this scenario, a country could adopt a regulation tailored to keep business profitable for the existing manufacturer and cost-prohibitive for the newcomer. ${ }^{156}$ Trade barrier protection is evidenced by other regulated industries.

Extensive pre-clearance inspection requirements of shelled walnuts and significant delays in reviewing U.S. documentation of pest mitigation for cherries and apples exported to the Republic of Korea, has effectively precluded market access for such products. Korea has also tended to prohibit certain food ingredients, additives (e.g., food colors and dyes) and manufacturing processes that are generally recognized as safe by international standards bodies .... ${ }^{157}$

149. Fahmida Khatun, Environment Related Trade Barriers and the WTO 12, (Ctr. for Pol'y Dialogue Working Paper No. 77, 2009), available at www.cpd.org.bd/pub_attach/OP77.pdf.

150. See Daniel H. Cole \& Peter Z. Grossman, Principles of LaW and EConomics 60-61 (1st ed. 2005).

151. Jan G. Laitos, The Strange Career of Private Property and the Police Power, 40A ROCKY MTN. Min. L. INST. (SPECIAL ISSUE) 1, 14 (1995).

152. Interview with Robert Jorgensen, supra note 9.

153. Id.

154. Id.

155. Id.

156. Id.

157. Lawrence A. Kogan, Nat'l Foreign Trade Council, Inc., Looking Behind the CurTaIN: THE Growth of TRAdE Barriers that IgNore SOUNd SCIENCE 12-13 (2003), available at www.wto.org/english/forums_e/ngo_e/posp47_nftc_looking_behind_e.pdf. 
First and second adopters are especially concerned that a global standard could erode their nations' sovereign ability to create and modify their own regulations to address these manufacturer interests. ${ }^{158}$

\section{B. Technology and Infrastructure}

Technology and infrastructure issues also may prevent certain countries from adopting an international diesel emission regulation. One of the most significant challenges to lowering diesel exhaust pollution is the wide range of diesel fuel quality available throughout the world. In particular, "lower diesel fuel sulphur results in a direct reduction of the emissions of both sulphate particles and $\mathrm{SO}_{\mathrm{x}}$ emissions." ${ }^{.159}$ Higher sulfur content also prevents the use of modern clean-diesel technology by reducing the technology's life cycle. ${ }^{160}$ Particulate traps or diesel particulate filters (DPFs) "collect particulate matter as the exhaust gases pass through and can reduce particulate emissions by 80 [to] 90 percent using a catalytic reaction or an auxiliary heating element. ${ }^{, 161} \mathrm{High}$ sulfur fuel, however, can quickly clog a DPF, ${ }^{162}$ making this technology impracticable for regions of the world with higher sulfur content fuel. As a result, diesel particulate matter cannot be lowered until the sulfur content in fuel is lowered. ${ }^{163}$

Most of the world does not currently employ diesel fuel with the low levels of sulfur found in fuel in the United States and European Union. ${ }^{164}$ Fortunately, the United Nations Environment Programme (UNEP) is addressing fuel quality issues through the Partnership for Clean Fuels and Vehicles as a means to achieve lower global emission pollution. ${ }^{165}$ Most Asian countries now impose stringent diesel fuel sulfur limits because of the direct reduction in PM pollution and because advanced diesel pollution reduction technologies require

158. Interview with Robert Jorgensen, supra note 9.

159. ENSTRAT INT'LLTD., COST OF DIESEL FUEL DESULPHURISATION FOR DIFFERENT REFINERY STRUCTURES TYPICAL OF THE ASIAN REFINING INDUSTRY 4 (2003), available at www.unep.org/pcfv/PDF/PubADBSulphurReport.pdf.

160. Press Release, Natural Res. Def. Council, New Diesel Fuel Hitting Pumps Nationwide on October 15 Cuts Pollution, Enables New Low-Emission Engine Technology (Oct. 10, 2006), available at $\mathrm{http} / / \mathrm{www} . n \mathrm{ddc} . \mathrm{org} / \mathrm{media} / \mathrm{pressreleases/061010.asp.}$

161. About Clean Diesel, DIESEL TECH. FORUM, http://www.dieselforum.org/ index.cfm?objectid=607A6EA0-8153-11E0-89D2000C296BA163 (last visited Apr. 10, 2012); Interview with Rich S. Wagner, supra note 28.

162. See Press Release, supra note 160.

163. See U.S. Envtl. Prot. Agency, Heavy-Duty Highway Diesel Program, http://www.epa.gov/otaq/highway-diesel/ (last updated Aug. 18, 2009).

164. U.N. Envtl. Programme, Diesel Fuel Sulphur Levels: Global Status March 2012, http://www.unep.org/transport/pcfv/PDF/Maps_Matrices/world/sulphur/MapWorldSulphur_Ma rch2012.pdf (last visited May 8, 2012).

165. U.N. Envtl. Programme, Partnership for Clean Fuels and Vehicles, UNEP.oRG, http://www.unep.org/transport/pcfv/ (last visited Apr. 15, 2012). 
it. ${ }^{166}$ This is also why the EPA's 2007 on-highway diesel emission standards required reduced sulfur content in step with emission changes. ${ }^{167}$

Catalytic converters also face challenges to their widespread implementation. This technology "use[s] a chemical reaction to convert emissions into harmless substances. Some catalysts-such as selective catalytic reduction (SCR) devices and $\mathrm{NO}_{\mathrm{x}}$ absorbers-focus on nitrogen oxides and can reduce these emissions by 25 [to] 50 percent." ${ }^{.168}$ However, SCR devices require urea to treat the diesel exhaust and reduce $\mathrm{NO}_{x} \cdot{ }^{169}$ This requires an adopting country to have the infrastructure for urea production and distribution, ${ }^{170}$ which even the United States lacked as late as 2010. ${ }^{171}$

Modern diesels also use sophisticated electronic technology to control engine fueling and timing parameters, ${ }^{172}$ but developing countries are not capable of diagnosing and repairing these advanced-technology engines. ${ }^{173}$ Moreover, countries rarely experience infrastructure and technology challenges in isolation. The EPA's most stringent diesel regulation, the 2010 standard for on-highway trucks, requires additional infrastructure to support ultra-low sulfur diesel fuel, urea availability, and a service network capable of servicing diesel products with advanced electronic technology. ${ }^{174}$ Thus, a stringent standard, even with existing technology, could be costly to develop and unattainable by developing countries.

Despite the challenges of new technology implementation, unregulated countries can benefit from prior technological improvements as diesel manufacturers retire outdated, cost-prohibitive diesel technology. Unregulated countries are often secondary markets for manufacturers' phased out products. ${ }^{175}$ While these engines never represent the most modern diesel technology, they inevitably emit less pollution than the even older models currently in use. Unfortunately, phasing out older products can take a very long time. For example, Indiana-based Cummins Inc., ${ }^{176}$ a leader in diesel engine

166. ENSTRAT INT'L LTD., supra note 159, at 4. These technologies "are essential to achieve reductions of NOx and particulate matter above $70 \%$ to $80 \%$, and hence reverse the growing pollution trend due to the continuing growth of the vehicle fleets in Asia." Id.

167. See id.

168. About Clean Diesel, supra note 161.

169. U.S. ENVTL. PROT. AGENCY ET AL., supra note 13, ch. 3, at 21.

170. Interview with Rich S. Wagner, supra note 28; see generally SCOTT FABLE \& MICHAEL D. Jackson, UREa INFrastructure HuRdLes: Report on TIAX Selective CatalytiC REDUCTION UREA INFRASTRUCTURE STUDY (2002).

171. Interview with Rich S. Wagner, supra note 28; see generally RAYMOND SCHUBERT ET AL., EXECUTIVE SUMMARY FOR: SCR-UREA IMPLEMENTATION STRATEGIES UPDATE-FINAL REPORT (2006).

172. About Clean Diesel, supra note 161.

173. Interview with Rich S. Wagner, supra note 28.

174. U.S. ENVTL. Prot. AGENCY ET AL., supra note 13, ch. 3, at 21.

175. Interview with Rich S. Wagner, supra note 28.

176. Formerly Cummins Engine Co. 
manufacturing, ${ }^{177}$ no longer offers its outdated $\mathrm{N}-14$ model engine in the United States market but continues to manufacture the engine to be sold in other countries. ${ }^{178}$ Thus, waiting on engine phase-out cannot be considered a strategy for reducing air pollution from diesel exhaust emissions.

\section{THE ECONOMIC COSTS ASSOCIATED WITH MULTIPLE REGULATIONS}

The problems that arise from diesel exhaust pollution create competing interests among environmentalists, health organizations, industrialists, manufacturers, equipment users, and the general public. One obvious concern is the impact of ineffective regulations or unregulated pollutants on the global population's health. ${ }^{179}$ Under theories of welfare economics, these "costs must be internalized to the producers in order to ensure allocative efficiency." 180 Accordingly, diesel manufacturers should bear the burden of the air pollution their products create. ${ }^{181}$

The ideal solution for achieving allocative efficiency is simple: First, a country with a pollution problem adopts a regulation; second, the country enforces that regulation against engine manufacturers; and third, the public enjoys clean air. ${ }^{182}$ Unfortunately, the realities of the market complicate this process. Although diesel manufacturers bear the costs of compliance with a newly imposed regulation, ${ }^{183}$ they pass these costs on to the consumer by factoring them into the price of their products. ${ }^{184}$ The public also bears the costs incurred by the government in enforcing the regulation ${ }^{185}$ as well as the increased prices charged for services provided by the more expensive dieselpowered equipment. ${ }^{186}$

In the context of a single country adopting its own regulation and forcing companies selling products into its local market to comply, it is possible that these economic externalities do not inhibit the cost-effectiveness of pollution regulation. In fact, this microeconomic model has been accepted in the United States because the benefit of creating products for the U.S. market has outweighed the costs of doing so. However, because most manufacturers of

\footnotetext{
177. About Cummins, CUMMINS INC., http://www.cummins.com/cmi/ navigationAction. do nodeId $=1000 \&$ siteld $=1$ \&nodeName $=$ About + Cummins \&menuId $=1000$ (last visited Apr. 10, 2012).

178. See Worldwide Manufacturing Locations, CUMMINs INC., http://www.cummins.com/ $\mathrm{cmi} /$ navigationAction. do ?nodeId $=9 \&$ siteld $=1$ \&nodeName $=$ Worldwide + Manufacturing + Loca tions\&menuId=1002 (last visited Apr. 10, 2012).
}

179. See supra Part III.

180. COLE \& GROSSMAN, supra note 150 , at 233.

181. See id.

182. See id. at 19.

183. See infra Part V.B.

184. Cole \& GROSSMAN, supra note 150 , at 318.

185. See infra Part V.C.

186. Interview with Rich S. Wagner, supra note 28 
diesel-powered equipment are global companies, a macroeconomic analysis is more appropriate.

From this perspective, the same economic externalities suggest that a regulation is not always the most economically efficient solution to the pollution problem - especially when multiple regulations exist that address the same environmental concerns.

In 1991 the EPA issued one of the most comprehensive studies on the costs and benefits of a pollution regulation, The Benefits and Costs of the Clean Air Act, 1970 to $1990 .{ }^{187}$ The study reported that, in complying with U.S. air pollution regulations,

businesses, consumers, and government entities all incurred higher costs for many goods and services. The costs of providing goods and services to the economy were higher primarily due to requirements to install, operate, and maintain pollution abatement equipment. In addition, costs were incurred to design and implement regulations, monitor and report regulatory compliance, and invest in research and development. Ultimately, these higher costs of production were borne by stockholders, business owners, consumers, and taxpayers. ${ }^{188}$

Over the study's twenty-year span, the United States spent approximately $\$ 523$ billion implementing the Clean Air Act. ${ }^{189}$

\section{A. Adoption Costs}

The regulatory agencies of first adopting countries incur costs to develop, adopt, and implement their regulatory standards. ${ }^{190}$ Likewise, second adopter countries incur development costs in modifying first adopter regulations. Countries also perform economic impact analyses to ensure that the benefits of a new regulatory standard outweigh the added costs. ${ }^{191}$ The expense of adopting a regulation would be even higher for unregulated countries, as they would be starting from scratch. ${ }^{192}$

187. U.S. EnVtL. Prot. Agency, The Benefits and Costs of the Clean AIR ACt, 1970 to 1990: EXECUTIVE SUMMARY 2 (1997), available at http://yosemite.epa.gov/ee/epa/ eerm.nsf/vwAN/EE-0295-2.pdf/\$file/EE-0295-2.pdf.

188. Id.

189. Id.

190. See id.

191. Sand, supra note 122, at 256-57; e.g., Exec. Order No. 12,866, 3 C.F.R. $§ 638$ (1993).

192. See generally supra notes $169-70$ and accompanying text. 


\section{B. Compliance Costs}

Designing and developing new technology to meet emission requirements is also expensive. ${ }^{193}$ Even with compliance costs, however, manufacturers continue to invest in technology for sale in first adopter markets because the practice is economically beneficial. ${ }^{194}$ In first adopter countries, governmental agencies work closely with manufacturers when creating regulatory requirements; ${ }^{195}$ thus, the standards are more easily found and understood. ${ }^{196}$ In second adopter countries, global companies in today's market face a significant challenge in achieving compliance with pollution regulations. ${ }^{197}$ Diesel engine and equipment manufacturers suffer from the added costs of tailoring their product designs for compliance with the unique regulatory requirements of each foreign market. ${ }^{198}$

Cummins provides a good example of a global company trying to manage varying regulations. Cummins continues to report increased sales because of its strong performance in international markets, ${ }^{199}$ but the company faces challenges and added costs in navigating through multiple diesel exhaust regulations. ${ }^{200}$

As nations address emissions and regulate air pollutants, fuel efficiency and greenhouse gas emissions from our products, we must understand and comply fully with these regulations. Our challenge is to improve our global emissions compliance processes - from the point when a regulation is considered to

\footnotetext{
193. See Cummins Inc., United States Securities and Exchange Commission Form 10-K at 12 (2010), available

at http://www.sec.gov/Archives/edgar/data/26172/000104746910001435/a2196405z10-k.htm; Deere \& Company, United States Securities and Exchange Commission Form 10-K at 18 (2009), available at http://www.sec.gov/Archives/edgar/data/315189/ 000110465909070344/a09-32005_110k.htm.
}

194. See generally COLE \& GROSSMAN, supra note 150 (As a general principle, if it is not economically beneficial for a company to do business in a market, the company would not be selling products in that market).

195. Interview with Robert Jorgensen, supra note 9.

196. Id.

197. Id.

198. Id.

199. Press Release, Cummins Inc., Cummins Reports Sharply Higher Sales and Profits in the Third Quarter Led by Continued Strength in International Markets (Oct. 26, 2010), available at http://www.cummins.com/cmi/displayMoreNewsAction.do?strTitle=Cummins+reports+shar ply+higher+sales+and+profits+in+the+third+quarter+led+by+continued+strength +in + i\&strN ewsSummary=Cummins+reports+sharply+higher+sales+and+profits+in+the+third+quarter+1 ed+by+continued+strength+in+i\&strId $=\% 2 \mathrm{Ftemplatedata} \% 2 \mathrm{FC}$ Content $\% 2 \mathrm{FNews} \% 2 \mathrm{Fdata} \% 2$ Fen\%2FInvestorsAndMedia\%2FPressReleases\%2F2010\%2F26Oct2010_CumminsReportsSh arplyHigherSalesProfits\&dtPublishDate= 2010-10-26.

200. Interview with Robert Jorgensen, supra note 9. 
when we design and make a product and then the sales and service of that product in the market. ${ }^{201}$

Cummins also faces challenges due to the increasing global focus on greenhouse gas regulation of its products. ${ }^{202}$

In addition to design and production costs, diesel engine and equipment manufacturers must be concerned with the potential risks of noncompliance, such as financial penalties for failing to test a certain number of engines each year. ${ }^{203}$ Further, unique regulatory requirements effectively can ban a product that pollutes so closely to the standard that it could be considered noncompliant. ${ }^{204}$ As explained above, because South Korea requires an additional certification test, engines certified to European Union standards are not initially acceptable for sale in South Korea. ${ }^{205}$ Adding to the complexities and costs, a global corporation now has to prohibit the sale of this one product that does not comply with this one country's unique regulatory requirement. If every country were to create unique requirements similar to South Korea's, the cost of a manufacturer's total global product line could increase significantly.

The added costs to achieve individualized compliance could make it costprohibitive for a diesel manufacturer to offer products in second adopter countries with additional requirements. ${ }^{206}$ Unregulated countries, however, provide the opposite end of the spectrum. ${ }^{207}$ Companies have minimal, if any, investment cost to develop a product for the unregulated market because they can ship any product to one of these countries without fear of failing to meet regulatory requirements or being subjected to regulatory penalties. ${ }^{208}$ Therefore, a manufacturer is likely to participate in either a heavily regulated market or a regulation-free market if participation will create a profit. ${ }^{209}$

\section{Enforcement Costs}

Environmental regulations also require enforcement. China and India are two examples of second adopter countries that have poor air quality despite their enacted air pollution regulations. ${ }^{210}$ Chinese environmental policies are

201. CUMmins INC., supra note 26, at 21.

202. Id.

203. Interview with Robert Jorgensen, supra note 9.

204. Interview with Rich S. Wagner, supra note 28; see also supra notes $48-51$ and accompanying text.

205. Interview with Rich S. Wagner, supra note 28; see also supra notes $48-51$ and accompanying text.

206. Interview with Robert Jorgensen, supra note 9.

207. Id.

208. Id.

209. See id.; see supra notes $193-98$ and accompanying text.

210. See supra Part III.A. 
often "declarative and unrealistic" "211 and "inadequate enforcement [is] one of the key factors in China's deteriorating environmental situation."212 This regulatory ineffectiveness also has been influenced "by a lack of coherence among environmental regulations, conflicting interests at different levels of the administration, and insufficient technical capacity and resources available to environmental institutions to carry out their duties." ${ }^{213}$ Additionally, China's general policy framework has "favored [economic] development over the environment," resulting in "widespread non-compliance with [the country's] environmental requirements." ${ }^{214}$ Enforcement is so lax that "approved and installed air ... pollution control equipment is put in operation only at times when inspectors' visits are expected, as polluters are more interested in saving on operation costs" than protecting the environment. ${ }^{215}$ China's compliance performance is also poor because the Chinese government has limited tools to promote compliance and does not actively inform regulated entities of developments in environmental regulations. ${ }^{216}$

The costs and benefits related to environmental pollution and the regulations designed to fix them are difficult to quantify. ${ }^{217}$ " [C]osts are borne by industry and are reflected in reduced production and higher costs of goods and services. The value of benefits of environmental regulations, however, tends to be far more nebulous." ${ }^{, 218}$ Proponents of the unique regulations in China and South Korea might consider those additional requirements as a benefit for those nations, but secondary testing adds to an engine's expense without reducing its emissions. ${ }^{219}$ Thus, China, South Korea, and other second adopter markets would benefit more by achieving the next most stringent standard, improving fuel quality, or improving enforcement rather than spending their resources creating unique regulatory requirements for vehicles already certified for operation in Europe. Another recommendation is for these countries to accelerate their vehicle retirement program ${ }^{220}$ by creating incentives for equipment purchasers to invest in more modern, lower-polluting equipment. ${ }^{221}$

211. OECD, CHINA, supra note 95 , at 6 .

212. Id. at 5 .

213. Id. at 6 .

214. Id.

215. Id.

216. Id. at 6-7.

217. COLE \& GROSSMAN, supra note 150 , at 318.

218. Id.

219. Id.

220. U.S. ENVTL. Prot. AgenCy, The INTEgRated ENVIRONMENTAL STRATEgIES (IES) CoSTBENEFIT ANALYSIS IN SEOUL, SOUTH KOREA, T.1 (2009).

221. See COLE \& GRossman, supra note 150 , at 332. 


\section{THE BENEFITS OF HARMONIZATION}

A global diesel exhaust emission regulation might be the most economically efficient solution to the global diesel pollution problem. ${ }^{22}$ "Harmonized programs can avoid costly multiple design configurations to meet varying requirements, with associated cost savings to ultimate purchasers. In addition, with regard to international trade, harmonization reduces the cost of introducing a product into another country. ${ }^{, 223}$ The relative harmonization in 1997 of EPA and European Union nonroad mobile source emission standards was an important success for diesel engine and equipment manufacturers. ${ }^{224}$ "[I]n order to streamline engine development and emission type approval/certification for different markets ... [EU] Stage I/II limits were in part harmonized with US regulations[ and] [EU] Stage III/IV limits are harmonized with the US Tier 3/4 standards."225

\section{A. European Union}

Trade regulations in the European Union provide another powerful example of the benefits of harmonization. The European Union began with six countries in the 1950 s and expanded to twenty-seven countries by $2007 .^{226}$

One of the EU's main aims is economic progress. Over the past 50 years, and especially since the 1980 s, much has been done to break down the barriers between the EU's national economies and to create a single market where goods, people, money and services can move around freely. Trade between EU countries has greatly increased and, at the same time, the EU has become a major world trading power. ${ }^{227}$

In 1985 the European Union launched a broad initiative, the Internal Market, to remove trade barriers among participating countries by the end of $1992 .{ }^{228}$ Ten years after implementation, the European Union conducted a study

222. FAIZ, supra note 61 , at 1 .

223. Control of Emissions of Air Pollution from Nonroad Diesel Engines, 62 Fed. Reg. 50152, 50158 (proposed Sept. 24, 1997) (codified at 40 C.F.R. pts. 9, 86, 89); available at http://www.gpo.gov/fdsys/pkg/FR-1997-09-24/pdf/97-24237.pdf.

224. Interview with Robert Jorgensen, supra note 9.

225. Emission Standards, Europe, Nonroad Diesel Engines, supra note 44.

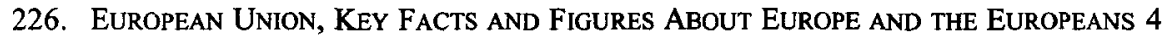
(2007), available at http://ec.europa.eu/publications/booklets/eu_glance/66/en.pdf.

227. Id. at 45 .

228. European Comm'n, THE Internal Market-Ten Years without Frontiers 4 (2003), available at http://ec.europa.eu/internal_market/10years/docs/workingdoc/ workingdoc_en.pdf. 
to understand the economic impact of the Internal Market, ${ }^{229}$ and the results reveal that the Internal Market was an overall success. ${ }^{230}$ Economically, the Internal Market delivered almost a two percent increase in the European Union's gross domestic product. ${ }^{231}$ Since 1992, the Internal Market created about 2.5 million jobs for European Union member countries that would not have been created without removing the trade barriers. ${ }^{232}$ The Internal Market enhanced the ability of companies within European Union member countries to compete in global markets and resulted in increased European exports to nonmember countries, from 6.9 percent of the European Union's gross domestic product in 1992 to 11.2 percent in $2001 .^{233}$ Direct investment into the European Union from foreign investors has also more than doubled as a percentage of gross domestic product over this same timeframe. ${ }^{234}$

Citizens and consumers of the European Union have also benefitted from having one market. ${ }^{235}$ The study performed by the European Commission found that 80 percent of European Union citizens believe the Internal Market created a wider choice of products, and that 67 percent believed the Internal Market created higher quality products. ${ }^{236}$ Prices for goods have also decreased as a result of expanding national markets and increased competition. ${ }^{237}$

Businesses have also benefited from the European Union's Internal Market because trade within the European Union has become much easier. ${ }^{238}$ "The absence of border bureaucracy has cut delivery times and reduced costs. Before the [creation of the Internal Market], the tax system alone required 60 million customs clearance documents annually . . .,239 Over 60 percent of companies that export to more than five European Union member countries believe that the Internal Market helped their cross-border sales. ${ }^{240}$ Small and medium-sized enterprises have been able to expand markets because costs and logistics to export goods no longer are prohibitive. ${ }^{241}$ New directives and regulations "replace[d] a large number of complex and different national laws with a single framework, often reducing compliance costs for businesses, who pass those savings on to consumers." 242

229. See id.

230. See generally id.

231. Id. at 2 .

232. Id.

233. Id.

234. Id.

235. Id.

236. Id.

237. Id.

238. Id. at 3 .

239. Id.

240. Id.

241. Id.

242. Id. 


\section{B. United Nations}

In the realm of vehicle safety, the Economic Commission for Europe, a division of the United Nations, has achieved great success through its harmonization work. ${ }^{243}$ Established in 1952, the Working Party on the Construction of Vehicles (Party) played a vital role in the development of standardized regulations within Europe. ${ }^{244}$ The Party was created in response to the United Nations' Convention on Road Traffic, which "identified vehicle characteristics as a major cause of road traffic crashes, deaths and injuries.",45 The Party gathered technical experts in order to establish standardized technical requirements for vehicles, such as a uniform standard for taillight configurations. ${ }^{246}$ The Party's first significant achievement was the Rome Agreement of $1956 .^{247}$ This agreement was significant because
it was the first step towards the official recognition of the need within Europe for an Agreement that not only addresse[d] the safety concerns posed by road traffic but also tackle[d] the problems of diverse state regulations which [disrupted] the free flow of commerce across state borders. Trade considerations were important at a time when Europe was in the process of reconstructing itself. The facilitation of safe and efficient transportation systems within Europe, which was the primary focus of the ITC, played an important role in that endeavour. $^{248}$

In March 2000 the Party changed its official name to World Forum for Harmonization of Vehicle Regulations (WP.29). ${ }^{249}$ "The growth of the world vehicle population and its impact on society, and the evolution of enginepowered vehicle markets from regional to global have focused [WP.29's] attention on ... [the] need to provide higher levels of vehicle safety, environmental protection, energy efficiency and vehicle security." ${ }^{, 250}$ These developments also highlighted "[the] need to reduce the diversity of regulatory requirements regarding vehicle safety and environmental performance in order to facilitate global commerce in these products.",251

243. See generally U.N. ECON. COMM'N FOR EUR., WORLD FORUM FOR HARMONIZATION OF VEHICLE REGULATIONS (2d ed. 2002), available at http://www.unece.org/trans/main/ wp29/wp29wgs/wp29gen/wp29pub/wp29pub2002e.pdf.

244. Id. at 5 .

245. Id

246. Id.

247. Id.

248. Id.

249. Id. at 6 .

250. Id at 1 .

251. Id. at 1 (emphasis added). 


\section{U.S. Coast Guard}

Other regulatory fields have also recognized the benefits of a more international approach to regulation. In 1996 the U.S. Coast Guard acknowledged the need for aligning its safety standards to those of international vessels and "amend[ed] its regulations for both inspected and uninspected vessels by removing obsolete, unnecessary, and excessive provisions and harmoniz[ed] regulations with international safety standards." ${ }^{252}$ The amendments were intended to "reduce the regulatory burden to industry by removing differences between requirements that apply to U.S. vessels in international trade and those that apply to similar vessels in international trade that fly the flag of responsible foreign nations."253

Alternatives to a global diesel regulation are available, but they often are unrealistic. One possibility is for a global company to be a leader in global environmental policy by voluntarily phasing out its higher polluting products. ${ }^{254}$ But because emission control technology increases costs and often fuel consumption, this approach could make a volunteering manufacturer's products uncompetitive in the market if other manufacturers do not take the same voluntary step. Another possible alternative could be that diesel engine manufacturers band together to "clean the air" by creating an effective environmental monopoly. For example, diesel manufacturers could agree to phase out older products and offer only the products the collective group believes are the lowest emitting engines for the products suitable to the region. This would advance an enhanced public image for diesel manufacturers and diesel technology, but it is unrealistic. Trying to get competing companies to agree on a collective strategy is difficult. Further, one company could initially agree on the collective action and then back out of the agreement after other companies have phased out their older products, giving the "holdout" company a significant economic advantage. ${ }^{255}$

\section{A Global REgUlation as tHE Most ECONOMICALLY EFFICIENT SOLUTION}

When the total cost of providing a product for a particular market outweighs the benefits, companies will cease to supply to that market. ${ }^{256}$ Conversely, unique regulations by one country could prevent a global company

252. Harmonization with International Safety Standards, 61 Fed. Reg 58804 (proposed Nov. 19, 1996), available at http://federalregister.gov/a/96-28407.

253. Id.

254. See supra notes $175-78$ and accompanying text.

255. See COLE \& GROSSMAN, supra note 150 , at 16 ; see infra note 280 and accompanying text.

256. See Cole \& Grossman, supra note 150 , at 17-18. 
from entering that market altogether. ${ }^{257}$ Manufacturers design and produce new products primarily to meet the demands of first adopter regulatory requirements, and a global manufacturer's best choice for a second adopter is one that has implemented a first adopter's regulation without modification. ${ }^{258}$ Unfortunately, this has proven difficult to achieve. ${ }^{259}$ Therefore, a global regulation may be the most efficient solution to achieve the best possible emission reduction for the lowest possible cost. ${ }^{260}$

Pollution is a social problem created by a company bringing its polluting products to the market. ${ }^{261}$ Under a classic nuisance law approach, the organization that brings the nuisance should bear its costs. ${ }^{262}$ Of course, any incremental costs in regulations supposedly addressing air pollution will be factored into the price of the equipment and passed on to the end consumer. ${ }^{263}$ Thus, when each second adopter country adopts its own version of a regulation, the country increases the consumer's costs. ${ }^{264}$ While the end consumer pays more, does the public benefit from cleaner air? Considering the air quality in China and India, the answer is probably no. ${ }^{265}$ The public could receive the same benefits if the country adopted and enforced an "off the shelf" regulated product rather than implementing its unique, additional requirements. A second adopter country could spend the money it would have spent modifying a first adopter's regulation and apply it toward enforcement against pollution violations in that country. ${ }^{266}$

Traditionally, international environmental standards have not proven to provide the highest social gain for the lowest total cost. This is because previous international standards have been established through treaties, ${ }^{267}$ an

257. See supra note 198.

258. Interview with Robert Jorgensen, supra note 9.

259. See supra Part IV.

260. See generally Ronald H. Coase, The Problem of Social Cost, 3 J.L. \& Econ. 1 (1960) (explaining that the goal of any regulation should be to provide the highest social gain for the lowest total cost). "It would clearly be desirable if the only actions performed were those in which what was gained was worth more than what was lost. But in choosing between social arrangements within the context of which individual decisions are made, we have to bear in mind that a change in the existing system which will lead to an improvement in some decisions may well lead to a worsening of others. Furthermore we have to take into account the costs involved in operating the various social arrangements (whether it be the working of a market or of a government department), as well as the costs involved in moving to a new system. In devising and choosing between social arrangements we should have regard for the total effect." Id. at 23 .

261. See Cole \& GRossman, supra note 150 , at 314.

262. Id. at 117.

263. See id. at 318.

264. See id.

265. See supra Part III.A.

266. See supra Part V.C.

267. Sand, supra note 122, at 218. 
approach that is highly inefficient. ${ }^{268}$ Specifically, environmental treaties suffer from two inherent problems ${ }^{269}$ :

First, they are based on the consensus or unanimity of all participants because no sovereign state is obliged to sign or ratify any treaty. Unlike decisions by a national legislature, which normally result in a median standard that is determined by majority vote but also binds the outvoted minority, internationally agreed-upon standards thus tend to reflect the lowest common denominator, or the "bottomline." Second, parliamentary ratification takes time, so the effectiveness of international agreements is deliberately delayed. Unlike national laws - which can fix their own dates of application, even allowing for immediate applicability or amendmentmultilateral treaties can be brought into force, or amended, only after a specified number of signatories ratifies them. The purpose, of course, is to ensure a measure of reciprocity and to avoid situations in which initial compliance by a few diligent parties creates disproportionate benefits to the "free-riders" remaining outside the treaty. Setting a threshold number, however, also delays implementation to the speed of the slowest boat in the convoy. ${ }^{270}$

Consider the WTO and Article XX of its General Agreement on Tariffs and Trade (GATT) ${ }^{271}$ The WTO's primary function is liberalizing trade, but Article XX "allows WTO member countries to use trade measures to protect the environment even when the measures are inconsistent with GATT., ${ }^{272}$ This exception provides an avenue for a country to create an environmental regulation that may function as an unnecessary trade barrier. ${ }^{273}$ Article $\mathrm{XX}$ also promotes many regional trade agreements, which can lead to economic trade inefficiencies in a global economy. ${ }^{274}$

While treaty negotiating between two countries is inefficient and

268. Id. at $219-20$.

269. Id.

270. Id. at 219.

271. General Agreement on Tariffs and Trade, art. XX, Oct. 30, 1947, 61 Stat. A-11, 55 U.N.T.S. 194.

272. Khatun, supra note 149, at 12.

273. See id.

274. See Peter Gallagher \& Ysé Serret, Environment and Regional Trade Agreements: Developments in 2009, (OECD Trade \& Env't Working Paper No. 2010/01), available at http://www.oecd-ilibrary.org/environment-and-regional-trade-agreements

$5 \mathrm{~km} 7 \mathrm{jf} 84 \mathrm{x} 4 \mathrm{vk}$.pdf?contentType=/ns/WorkingPaper\&itemId $=/$ content $/$ workingpaper $/ 5 \mathrm{~km} 7 \mathrm{jf8}$ $4 \mathrm{x} 4 \mathrm{vken} \&$ containerItemId $=/$ content/workingpaperseries $/ 18166881$ \&accessItemIds $=\&$ mime $T$ ype=application/pdf. 
multilateral treaties do not achieve the lowest pollution results, the current system, which lacks regulation, is also not the best possible outcome. A reasonable global regulation would allow for economies of scale, which in turn could lower a company's costs by reducing design and manufacturing complexity. ${ }^{275}$ If a global company knew that it could ship the same engine or equipment to any country without worrying about unique regulatory requirements, including something as simple as product labeling, it could reduce production costs. ${ }^{276}$ This practice could increase the net social benefit of lower pollution by introducing lower-polluting products into a market without additional costs for a company to enter that market. ${ }^{277}$

Improved public health would be an additional benefit of a global regulation. While difficult to quantify economically, public health could improve through reduced diesel exhaust pollutants if clean-diesel products were more readily available. It follows that adopting a global diesel emission standard could create a more efficient means of lowering regulated pollutant levels and making clean-diesel products more available. This aspect will become particularly important as the world begins regulating greenhouse gases. ${ }^{278}$ If, for example, the international community wishes to lower the limits of $\mathrm{CO}_{2}$, which may impact $\mathrm{NO}_{\mathrm{x}}$ output, the problem would be better resolved through an international forum such as the United Nations or World Trade Organization rather than through each individual country. ${ }^{279}$

A global regulation also could improve compliance because second adopter countries currently assess their own penalties for different infractions. ${ }^{280}$ Consistent regulations, clearly understood by regulated entities, would increase the likelihood that a company would remain in compliance with known regulations and reduce its risk of financial penalties. ${ }^{281}$ In addition, a global regulation may help phase out older products or reduce the number of products created for second adopter countries because the volumes demanded for these unique products may diminish to the point where it no longer makes financial sense for a company to offer the product. ${ }^{282}$ For instance, assume that ninety-five percent of countries adopt the global standard. Unless the volume is considerably high, the diesel manufacturers in the remaining five percent may not wish to produce products custom-tailored for the remaining market. ${ }^{283}$

In order for a global diesel regulation to be accepted, an appropriate

275. See Cole \& GROSSMAN, supra note 150 , at 305-06.

276. See supra Part V.B.

277. See supra Part V.A.; see supra note 75 and accompanying text.

278. See Interview with Robert Jorgensen, supra note 9.

279. See id.

280. See id.

281. See id.

282. See id.

283. See id. 
regulated standard is required. ${ }^{284}$ However it would be unwise for a country with no fuel infrastructure to support the most stringent emission levels. ${ }^{285}$ This would be cost-prohibitive for end consumers as well as a disaster in terms of reliability and emissions performance of the diesel products. ${ }^{286}$ Opponents of international regulations fear that there will be a "lowest common denominator problem," where the adopted international standard would be the least stringent available because it is all poorer countries can afford. ${ }^{287}$ However, this approach may not be a bad starting point-regulations must begin somewhere. ${ }^{288}$ Creating an emission standard to the lowest common denominator could develop and eventually reduce future emission levels more efficiently. ${ }^{289}$

An international regulation would not require all countries to adopt the same standard; it would require only that countries adopt one standard consistent with the fuel and service infrastructure available. ${ }^{290}$ If a country wishes to impose only the lowest possible regulated emission level, other countries are free to adopt more stringent emission levels as long as the regulations implementing the more stringent levels are also standardized. ${ }^{291}$ First adopters have several standards which could be applied in all markets. ${ }^{292}$ An international standard could require only that a country choose and accept a standard which works best for its society. ${ }^{293}$

A reasonable approach to create an infant international standard would be to adopt a regulation similar to the IMO's $\mathrm{NO}_{\mathrm{x}}$ Technical Code. ${ }^{294}$ This approach allows countries that require further reduction standards to achieve those goals. ${ }^{295}$ Under Tiers II and III and the provision for Emission Control Areas (ECA), ${ }^{296}$ the IMO requires all participating parties to have at least IMO Tier I requirements. ${ }^{297}$ For the countries wanting to reduce emissions even further, a country can adopt the lower standards of IMO Tier II or can petition the IMO to create ECAs which are certain coastal boundaries that require compliance with IMO Tier III. ${ }^{298}$

284. See id.

285. See id.

286. See id.

287. See id.

288. See id.

289. See id.

290. See id.

291. See id.

292. See id.

293. See id.

294. Int'l Mar. Org., Amendments to the Technical Code on Control of Emission of Nitrogen Oxides from Marine Diesel Engines (NOx Technical Code 2008), Res MEPC.177(58)(Oct. 10, 2008).

295. See Interview with Robert Jorgensen, supra note 9.

296. See id.

297. See id.

298. See id. 
Enforcement also plays a significant role in pollution control. ${ }^{299}$ Without enforcement, a company faces little risk in not complying with existing regulations. ${ }^{300} \mathrm{~A}$ global diesel regulation would provide an affordable way to achieve enforcement. ${ }^{301}$ Rather than a country spending money creating a regulation, it can spend money enforcing an existing regulation. ${ }^{302}$ Countries that do not have enforcement agencies have found that by adopting the IMO standards, they can generate revenue through compliance enforcement by fining vessels that do not comply with IMO standards. ${ }^{303}$ These fines eventually could trickle down to the end consumers through higher shipping costs. ${ }^{304}$ However, if companies consistently fail to follow the regulations, they most likely will price themselves out of the market because their services could not compete with companies that do follow the regulations. ${ }^{305}$ This would be beneficial to the public because society wants to discourage companies from polluting.

\section{CONCLUSION}

The world will benefit both economically and socially if it adopts a global diesel regulation for diesel exhaust emissions. Reducing the number of ineffective and/or redundant diesel exhaust emission regulations will allow higher quality products with lower diesel exhaust emissions to be delivered to the markets at lower costs. Successes can be achieved like those of the European Union's Internal Market and other harmonized regulatory systems. ${ }^{306}$

While an international agreement will be difficult to achieve, ${ }^{307}$ the alternative of uncontrolled pollution in the wake of new regulations for greenhouse gas emissions could prove more problematic. ${ }^{308}$ Although the United Nations has no power to enforce a global regulation, it could propose an infant, harmonized regulation where countries could voluntarily adopt and enforce the provisions of the regulation. An example is shown in Table 2 below. The regulation can be arranged by considering both the fuel quality and service infrastructure available, and a country can adopt and enforce the regulation which best suits its needs. This approach could reduce the difficulties that global companies have with complex regulations, provide a cost-effective means for a country to reduce its pollution levels, allow countries to spend their resources on enforcement rather than the creation of additional

299. See id.

300. See id.

301. See id.

302. See id.

303. Interview with Rich S. Wagner, supra note 28.

304. Id.

305. Id.

306. See supra Part V.

307. See generally Sand, supra note 122.

308. Interview with Robert Jorgensen, supra note 9. 
regulation requirements, and serve as a stepping stone for an global $\mathrm{CO}_{2}$ regulation. Countries also would be free to choose the timing for which the international standard is adopted. The United Nations should create a global diesel exhaust regulation similar to the International Maritime Organization's $\mathrm{NO}_{\mathrm{x}}$ Technical Code in order to create a more efficient and sustainable global economy.

Table 2: Proposed International Global Regulation ${ }^{309}$

\begin{tabular}{|c|c|c|c|c|}
\hline \multicolumn{5}{|c|}{ International Standard - LevelI } \\
\hline Application & Accepted Regulation(s) & Allowable Fuel Sulfur Levels & Infrastructure & Examples \\
\hline On-highway & EPA 1990 or E-91 & $2500 \mathrm{ppm}$ & Developing & \multirow{4}{*}{$\begin{array}{l}\text { Any unregulated } \\
\text { countries }\end{array}$} \\
\hline Nonroad & EPA Tier 1 or EU Stage 1 & Any & Developing & \\
\hline Marine & EPA TIER 1 & Any & Developing & \\
\hline Locomotive & EPA TIE 0 & Any & Developing. & \\
\hline \multicolumn{5}{|c|}{ International Standard - Level II } \\
\hline Application & Accepted Regulation(s) & Allowable Fuel Sulfur Levels & Infrastructure & Examples \\
\hline On-highway ${ }^{1}$ & EPA 1991, Euro II or Euro ill & $<500 \mathrm{ppm}$ & Moderate & \multirow{4}{*}{$\begin{array}{l}\text { Second adopters such as } \\
\text { China, India, Mexico, } \\
\text { and South Korea }\end{array}$} \\
\hline Nonroad & EPA Tiers 2 or 3, EU Stage II or Stage III A & $<500$ ppm & Moderate & \\
\hline Marine & EPA Tiers 2 or 3 , EU Stage III A & $<500$ ppm & Moderate & \\
\hline Locomotive & EPA Tiers 2 or 3 , EU Stage IfI A & $<500$ ppm & Moderate & \\
\hline \multicolumn{5}{|c|}{ Intemational Standard - Level III } \\
\hline Application & Accepted Regulation(s) & Allowable Fuel Sulfur Levels & Infrastructure & Examples \\
\hline On-highway & EPA 2007 or 2010 , Euro V or VI & $<15$ ppm & Sophisticated & \multirow{4}{*}{$\begin{array}{l}\text { First adopters such as } \\
\text { United States, European } \\
\text { Union member } \\
\text { countries, and Japan }\end{array}$} \\
\hline Nonroad & EPA Tier $4 \mathrm{i}$ or Tier 4, EU Stage III 8 or EU Stage IV & $<15 \mathrm{ppm}$ & Sophisticated & \\
\hline Marine & EPA TIER 4 & $<15 \mathrm{ppm}$ & Sophisticated & \\
\hline Locomotive & EPA Tier 4 , EU Stage III B & $<15 \mathrm{ppm}$ & Sophisticated & \\
\hline
\end{tabular}

Note 1: Possible use of EU Stage IV if fuel sulfur level less than $50 \mathrm{ppm}$ 